\title{
THE CIVIC SELF-CONSCIOUSNESS OF CONTEMPORARY SECONDARY SCHOOL STUDENTS IN THE ASPECT OF THE HUMANISTIC PARADIGM OF EDUCATION
}

\author{
Roman Alijev \\ Riga Classical Gymnasium, Latvia \\ Zoja Chehlova \\ University of Latvia, Latvia \\ Ingrida Kevisa \\ Latvian Academy of Culture, Latvia \\ Mihail Chehlov \\ Riga Secondary School No.15, Latvia
}

\begin{abstract}
Civic self-consciousness is a topical issue in present-day Latvia. After regaining of independence and joining the European Union, there appeared an opportunity to ensure real freedom and genuine democracy for all inhabitants in Latvia. Thus, new conditions were created for the development of civic self-consciousness in senior secondary school students. New guidelines are developed in the European system of education according to the new understanding of humanism. The key reference-point is the understanding that the main goal of education is to support the development of personality that will become an EU citizen and a professional. The study established that it is necessary to develop civic self-consciousness so that Latvian secondary school students could become European-type citizens and professionals. The research deals with the analysis of a new model of education, the basis for developing civic self-consciousness in senior secondary school students. The research has determined the structure of civic self-consciousness and demonstrated the interconnectedness of its structural components (tolerance, responsibility and intercultural identity).

The aim of the research: to analyse the possibilities of a new model of education in developing the civic self-consciousness of senior secondary school students, to determine its essence, structure and characteristics. The research methods include analysis, survey, testing, conversation, an ascertaining experiment, mathematical statistics.

The research results: there was determined the structure of civic self-consciousness as a precondition for the development of civic self-consciousness in senior secondary school students and conducted the analysis of ideas concerning new humanism in education and a new model of education (education - culture - individual).
\end{abstract}

Keywords: civic self-consciousness, humanistic paradigm of education, identity, responsibility, the cultural component of education, tolerance. 
Alijev et al., 2020. The Civic Self-Consciousness of Contemporary Secondary School Students in the Aspect of the Humanistic Paradigm of Education

\section{Introduction}

The topicality of the issue concerning the development of civic selfconsciousness of Latvian youth is underpinned by social and political transformations taking place in Europe and in Latvia in the 21st century (the creation of the European Union and Latvia's accession to the European Union). The importance of tacking this issue in Latvia was also highlighted by the president of Latvia Egils Levits in his New Year address on the $31^{\text {st }}$ of December 2019. In this regard, it has become necessary to create a new model of education based on the humanistic paradigm. The humanistic paradigm of education presupposes the transition from utilitarian and pragmatic goals of education as a combination of knowledge, skills and abilities necessary for successful professional activity to a humanistic goal focused on the subject and his/her personal development. In 2006, a humanitarian model of education was developed in Latvian science, in accordance with the humanistic ideas aimed at educating a European citizen (Čehlovs, 2011). The title "humanitarian model of education" emphasizes the focus on the person as the highest value. Consequently, the humanitarian model of education is considered in contemporary pedagogy as the basis for the development of the civic self-consciousness of senior secondary school students.

The research object - the humanitarian model of education.

The research subject - the civic self-consciousness of contemporary senior secondary school students.

The aim of the research - to analyse the possibilities of a new model of education in developing the civic self-consciousness of senior secondary school students; to determine the essence, structure and characteristics of the civic selfconsciousness of senior secondary school students.

The research methodology - the research was carried out using the following approaches: the humanistic approach, the personal activity approach, the cultural approach and the competency-based approach.

The research methods - analysis, survey, testing, conversation, an ascertaining experiment, mathematical statistics (the data processing was done using the software SPS16).

The research basis - Riga Classical Gymnasium, Riga State Technical School, and Teterov Gymnasium in Germany.

\section{The European Dimension in Education: Reorganizing the Traditional System}

The European system of education has developed new guidelines in accordance with the new understanding of humanism. They have been formulated 
by Y. Neimatov in the monograph "Education in the $21^{\text {st }}$ century: the trends and predictions" (Neimatov, 2002). The new guidelines set in this work correspond to new ideas about education and serve as the basis for the reorganization of the traditional system of education.

The first postulate is that the aim of education is the formation of a person who will become a European-type citizen and a professional who upholds tolerance and pluralism, appreciates the cultural heritage of society, is a conscious participant in the process of European integration, a person with a developed civic consciousness. The task of education is to teach the young person how to change living conditions and improve them, rather than accept them passively from the previous generations, to cultivate valuable relations with the state whose citizen a particular person is.

The second postulate concerns the socialization of a personality in a multicultural society. In this regard, a new understanding of culture appears. The contemporary culture is the aggregate of interacting cultures in society, the space of human coexistence, while common cultural values serve as the basis of intercultural interaction.

The third postulate shifts the focus in the process of education from a teacher to a learner. A learner is a subject with individual characteristics, abilities and aspirations. This is a personality who opens and creates culture in society where he/she independently forms himself/herself and becomes a free citizen.

The fourth postulate is that real life and direct experience are the main sources of contemporary learning. Education should be brought closer to contemporary life and take place in collaboration.

The fifth postulate is that general cultural values and the common philosophical principles of education (the principles of equality and freedom), the recognition of human rights, including the right to education for all, constitute the basis for the harmonization of contemporary education. The civic selfconsciousness is seen as a general cultural value.

These guidelines constitute the theoretical framework for the reorganization of the traditional system of education and the creation of a new model of education.

\section{“The Humanistic Dimension in Education": Creation of a Humanitarian Model of Education}

In the $21^{\text {st }}$ century, there arose a need to develop a new model of education both in the European and Latvian systems of education in the context of the humanistic paradigm. Humanization is a socio-cultural position that derives from the priority of a human being as the highest value, which implies the restructuring of the whole culture and, consequently, the entire system of education in a homo- 
Alijev et al., 2020. The Civic Self-Consciousness of Contemporary Secondary School Students in the Aspect of the Humanistic Paradigm of Education

centric direction. The essence of this refocusing lies in the implementation of the ideas of new humanism: from an individual as an object of education (a passive recipient of information) to an individual as a subject of education, capable of self-education and self-development (Alijevs, 2005). The new humanistic paradigm of education presupposes a transition from utilitarian and pragmatic goals of education as the aggregate of knowledge, skills and abilities to a humanistic goal focused on the subject and his/her personal development. The humanistic paradigm of education involves a change in its goals. The goal is the development of personality, the formation of individuality, not only the formation of professional suitability, i.e., the acquisition of knowledge and skills. The principal relationship of the educational process "teaching - learning" is changing. It is specified by taking the cultural component into account and acquires the content "education - culture - person". In the humanitarian model of education, content is culture as a system of universal human values. The cultural component of the content of education in the humanitarian model consists of the following interrelated elements:

- the subject content, including the cultural experience of humanity in the form of knowledge;

- the communicative-activity content, revealing the kinds of human activity and communication in the cultural system;

- creativity as the transformation of activities into new conditions;

- $\quad$ subjective content, including personal socio-cultural experience of emotional value-based relationships (motives, interests, meanings) (Čehlovs, 2011).

Understanding of contemporary education as a cultural phenomenon corresponding to the trends and dynamics of present-day culture changes the nature of education and expands the scope of design, helping its subjects to tackle innovative, high-quality and value-based tasks. Therefore, it is necessary to expand the cultural content of the key educational processes: teaching, upbringing and pedagogical support (Neimatov, 2002). It implies a different value-based filling of the processes of teaching and upbringing, i.e., a different culture that cannot be studied. Culture is absorbed in communication and in general life activity; this is just what our education is deprived off, still being aimed at the effective implementation of the knowledge-based approach (Matsumoto, 2007). As a result of replacing the disciplinary knowledge-based dominant of education with the dominant of cultural activity and creativity, independent creative activity (productive and practical, not only cognitive) of secondary school students becomes the principal educational space. This is a pre-condition for the development of the civic self-consciousness of contemporary secondary school students. The elaborated humanitarian model of education represents a meta- 
structure. Various pedagogical phenomena can be structured based of this model, including the development of the civic self-consciousness of secondary school students, both as a phenomenon and a process. The concept of the "humanitarian model" draws attention to another important idea: this concept focuses on the natural essence of pedagogy as part of the humanities. There is another important idea: the humanitarian nature of pedagogy suggests the need to develop a humanitarian paradigm of education as its own methodological basis for the study of pedagogical phenomena and processes (Čehlova, 1995; Chehlova, Chehlov, \& Gode, 2019).

\section{The Essence of Civic Self-Consciousness}

There is an opinion in academic literature that civic identity is a non-national identity, since there are virtually no countries with $100 \%$ mono-ethnic population (Ross, 2006). Different ethnic groups have always lived in Latvia as well; therefore, we agree with the opinion that civic self-consciousness is really a nonnational entity. We are all the citizens of Latvia, and we share a common goal the prosperity of our country. Scholars regard civic self-consciousness as an integrative personal quality, comprising inner freedom and respect for state authorities, love for one's homeland and self-actualization in professional activity for the benefit of society (Ginzburg, 1994). In the last decades, the content of this concept has been enriched with new ideas; this is due to socio-political changes that have taken place in Europe (the creation of a single European educational space and a single labour market). This implies the education of a European-type citizen. Researchers identify psychological, pedagogical and social aspects in the content of civic self-consciousness.

The content of civic self-consciousness of a contemporary secondary school student includes civic responsibility, tolerance and intercultural identity (Krzywosz-Rynkiewicz, 2012; Ross, 2013). Each of these properties is an integrative formation based on social values (Neimatov, 2002). We regard the attitude to the state as a value as the core of civic responsibility. At the core of tolerance, we see the treatment of another person as a value (Chehlova, Kevisha, \& Chehlov, 2013). At the core of European identity, we see the attitude to the cultural diversity in Latvia and in the world as a value (Spinthourakis, Acar, \& Korhonen, 2010). The development of the civic self-consciousness of a secondary school student is a topical issue since civic self-consciousness contributes to the development of a European citizen and the development of a personality competitive in the labour market (Chehlova, 2006; Chehlov \& Chehlova, 2015). The objective of the study was verified in the course of an ascertaining experiment. 
Alijev et al., 2020. The Civic Self-Consciousness of Contemporary Secondary School Students in the Aspect of the Humanistic Paradigm of Education

\section{A Study of the Development of Civic Self-Consciousness in a Contemporary Secondary School Student \\ The Aim and the Programme of the Ascertaining Experiment}

The aim of the experiment was to analyse the development of integrative properties of the civic self-consciousness of secondary school students: civic responsibility, tolerance and European identity. There was used a personal maturity test questionnaire (Gilbuh, 1995). The research methods used in the experiment included observation, surveying, interviewing, testing and mathematical statistics. The experiment was carried out in the $12^{\text {th }}$ form of Riga Classical Gymnasium (60 students), Zolitude Gymnasium (55 students), Riga State Technical School (50 students) and Teterov Gymnasium in Germany (20 students).

\section{The Study of Civic Responsibility}

The study of civic responsibility was conducted by means of the questionnaire "Where do you want to study and work?”.

Table 1 Students' answers to the question "Where do you want to study and work?"

\begin{tabular}{|l|c|c|}
\hline School & Own country (\%) & Another country (\%) \\
\hline Riga Classical Gymnasium & 40 & 60 \\
\hline Zolitude Gymnasium & 39 & 61 \\
\hline State Technical School & 38 & 62 \\
\hline Teterov Gymnasium (Germany) & 90 & 10 \\
\hline
\end{tabular}

The analysis of the results of the survey (see Table 1) indicates that most of the secondary school students are going to work abroad (60\%), whereas $40 \%$ intend to work in Latvia. The trend of young people emigrating is continuing. The respondents are planning to study in various countries, depending on their interests and language skills. We saw different results in a German school - 90\% of those questioned intend to work in Germany, and only $10 \%$ would like to work abroad. These results imply that senior secondary students in Latvia have relatively little interest in the occurrences in public life. Their priorities are personal well-being and their professional career. This is because the economic situation in Latvia is less favourable than in wealthier European countries. In Germany, the top priorities for senior secondary school students are good education, high salaries and a professional choice. 


\section{The Study of Inter-Cultural Identity}

The attitude to the diversity of the cultures of Latvia and the European Union as a value is considered as the basis of inter-cultural identity. The study was conducted using the testing method (test "Your life priorities"). The the test results show that secondary school students demonstrate a high level of desire to be welleducated, cultural and respected individuals; they also want to occupy a significant position in society and be competitive in the labour market not only in Latvia, but also in the whole European Union. The analysis of the results also indicates that the students display a high level of interest in the diverse cultures of the European Union. This is especially true for the students of Riga Classical Gymnasium. This is due to the fact that the gymnasium provides the possibility of studying various languages, including Latvian, Russian, English, French, German, Spanish and Latin. Consequently, senior secondary school students are aware of the styles of social behaviour, and they know that inter-cultural dialogue is a natural and effective way of cultural interaction that enriches everyone.

\section{The Study of Tolerance}

The attitude to the other as a value constitutes the basis for the development of tolerance in secondary school students. The authors analysed the concept of tolerance based on the Declaration of the Principles on Tolerance adopted by the UNESCO General Conference in 1995. The study was conducted by means of the questionnaire "Attitude to the other as a value". The students were asked a question concerning their relations with their peers representing other nationalities.

Table 2 Students answers to the question concerning relationships with their peers of other nationalities

\begin{tabular}{|c|c|c|c|c|}
\hline Relationship & $\begin{array}{c}\text { Riga Classical } \\
\text { Gymnasium } \\
(\%)\end{array}$ & $\begin{array}{c}\text { Zolitude } \\
\text { Gymnasium } \\
(\%)\end{array}$ & $\begin{array}{c}\text { State } \\
\text { Technical } \\
\text { School (\%) }\end{array}$ & $\begin{array}{c}\text { Teterov } \\
\text { Gymnasium } \\
\text { (Germany) (\%) }\end{array}$ \\
\hline Excellent & 60 & 33 & 37 & 40 \\
\hline Friendly & 20 & 29 & 21 & 28 \\
\hline Good & 9 & 23 & 33 & 22 \\
\hline $\begin{array}{c}\text { No friends of } \\
\text { another nationality }\end{array}$ & 11 & 15 & 9 & 10 \\
\hline
\end{tabular}

The results of the survey (see Table 2) indicate that in Latvia the representatives of different nationalities mainly collaborate in various sports sections and interest groups. In this collaboration process, $90 \%$ of the 
Alijev et al., 2020. The Civic Self-Consciousness of Contemporary Secondary School Students in the Aspect of the Humanistic Paradigm of Education

representatives of different nationalities have friendly, excellent or good relationships, whereas $10 \%$ of those surveyed admit that they communicate only with the peers of their nationality because of poor knowledge of another language (Latvian/Russian). In the German gymnasium, the students watch films, sports programmes and educational programmes in English. It is worth noting that a lot of surveyed Latvian students lived in German families during their exchange programme, and now German and Russian students actively communicate online in the German Language.

\section{The Final Analysis of the Obtained Results}

The analysis of the results of the ascertaining experiment showed that the development of the civic self-consciousness of contemporary secondary school students is insufficient and requires further improvement. This is due to a number of objective reasons: the difficult economic situation in Latvia, a relatively high rate of unemployment (6\%), lack of jobs in the chosen specialty and fee-charging higher education. Subjective factors also play a significant role: insufficient development of readiness for social self-determination and decreased interest in social and political events; interest in one's professional career depending on material benefits prevails. The public orientation of choosing a profession for the benefit of society was low.

\section{Conclusions}

1. The humanitarian model of education is the basis for the development of civic self-consciousness of a senior secondary school student as it clearly expresses the humanistic idea of educating a moral person, a citizen of Latvia and a citizen of the European Union.

2. In the humanitarian model of education, the purpose of education is changing. The main goal is the development of personality, individuality, not only the formation of professional suitability, i.e., the acquisition of knowledge and skills.

3. In the humanitarian model of education, the cultural component - the system of universal human values - becomes part of its content.

4. The essence and structure of civic self-consciousness has been determined: civic self-consciousness is an integrative property of a person. Its components are civic responsibility, tolerance and cultural identity.

5. The development of tolerance and European identity as the components of civic self-consciousness is at an optimal and high level.

6. The development of civic responsibility needs to be advanced. 


\section{Methodological conclusions:}

- $\quad$ The natural essence of pedagogy as a humanitarian discipline has been revealed;

- $\quad$ Further development of the humanitarian paradigm of education as the methodological basis for the study of pedagogical phenomena and processes is needed;

- The elaborated humanitarian model of education represents a metastructure on whose basis various pedagogical phenomena and processes can be structured, including the development of the civic selfconsciousness of contemporary secondary school students.

\section{References}

Alijevs, R. (2005). Izglītibas filosofija 21. gadsimts [Philosophy of education in the $21^{\text {st }}$ century]. Rīga: Retorika A.

Čehlova, Z. (1995). Skolēnu personības attīstība mācību procesā [The development of students’ personality in the process of learning]. Rīga: Latvijas Universitāte.

Čehlovs, M. (2011). Vidusskolēnu pašnoteikšanās attīstības humanitārie aspekti [The humanitarian aspects of the self-determination of secondary school students]. Rīga: RAKA.

Chehlov, M., \& Chehlova, Z. (2015). The development of the professional self-determination of senior secondary school students in the process of specialized education. Society, Integration, Education. Rēzekne: Rēzeknes Augstskola.

Chehlova, Z. (2006). The Development of Citizenship for Senior Form Students in the Schools of National Minorities. Citizenship Education: Europe and the World. London: CiCe.

Chehlova, Z., Chehlov, M., \& Gode, I. (2019). Pedagogical Conflict - the Contemporary Technology of the Competency-Based Approach. Society, Integration, Education. DOI: http://dx.doi.org/10.17770/sie2019vol2.3722

Chehlova, Z., Kevisha, I., \& Chehlov, M. (2013). Pedagogical conditions for the development of citizenship for senior secondary school students in Latvia. Identities and citizenship education: Controversy, crisis and challenges. Lisbon: CiCea.

Gilbuh, J. (1995). Test-oprosnik lichnostnoi zrelosti [Personal maturity questionnaire]. Kiiv.

Ginzburg, M. (1994). Psihologicheskoe soderzhanie lichnostnogo samoopredelenija [The psychological content of personal self-determination]. Voprosy psihologii [Issues in psychology], 3. Moskva: Prosveschenie.

Golovaha, E. (1988). Zhiznennie perspektivy i professionalnoe samoopredelenie molodezhi [The life prospects and professional self-determination of young people]. Kiiv: Pedagogika.

Krxywosz-Rynkiewicz, B. (2012). Responsibility as a personal, local and global phenomenon. Creating Communities: Local, National and Global. York: CiCea.

Matsumoto, D. (2007). Culture and Psychology. Wadsworth Publishing Company.

Neimatov, Y. (2002). Obrazovanie v XXI veke: tendencii i prognozy [Education in the $21^{\text {st }}$ century: the trends and predictions]. Moskva: Algorytm.

Ross, A. (2006). Introduction: Constructing Citizenship through Teaching. Citizenship Education: Europe and the World. London: CiCe. 
Alijev et al., 2020. The Civic Self-Consciousness of Contemporary Secondary School Students in the Aspect of the Humanistic Paradigm of Education

Ross, A. (2013). Intersecting identities: young people's constructions of identity in south-east Europe. Identities and citizenship education: Controversy, crisis and challenges. Lisbon: CiCea.

Spinthourakis, J., Acar, E.A., \& Korhonen, R. (2010). Primary and early childhood teacher education and multicultural efficacy. Lifelong Learning and Active Citizenship. Bratislava: CiCea.

UNESCO. (1995). Declaration of principles on tolerance. Retrieved from http://portal.unesco.org/en/ev.php-

URL_ID=13175\&URL_DO=DO_TOPIC\&URL_SECTION=201.html 